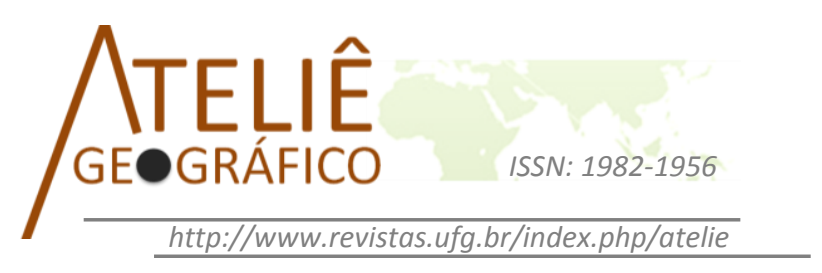

\title{
Circulación del capital y división del trabajo: reorganización de la red financiera y reestructuración del sistema bancario en Argentina (1991-2008)
}

\section{Circulação do capital e divisão do trabalho: reorganização da rede financeira e reestruturação do sistema bancário na Argentina (1991-2008)}

\author{
Circulation of capital and division of labour: financial \\ network's reorganization and bank system's reestructuration \\ in Argentina (1991-2008)
}

Sebastián Gómez Lende

Universidad Nacional del Centro de la Provincia de Buenos Aires

gomezlende@yahoo.com.ar

\begin{abstract}
Resumen
Operando a partir de una lógica coherente e instrumental, las redes forman sistemas que, permitiendo la circulación del capital, presiden la reproducción y evolución del espacio geográfico, fracturando a cada país en hombres rápidos y lentos, en áreas luminosas y letárgicas. Las finanzas no evaden esa ley general. En este trabajo, se estudia la reorganización de la red financiera y del sistema bancario en Argentina entre 1991 y 2008 para caracterizar el actual proceso de racionalización y fragmentación del territorio nacional. El análisis de los objetos, las acciones y las normas que componen esa peculiar división del trabajo y la interpretación de los factores externos (crisis internacionales, regulaciones globales, estrategias de acumulación del capital extranjero) e internos (papel del Estado, funcionamiento técnico y político del circuito, relaciones con otras formas y estructuras espaciales) que la gobiernan -vía indicadores como la globalización y concentración económica y empresarial del sector, las densidades territoriales del tejido bancario, su nivel de automatización y los movimientos de capital-dinero- revelarán, a escala provincial y departamental, la constitución de áreas luminosas plenamente integradas y zonas letárgicas excluidas.
\end{abstract}

Palabras clave: circulación del capital; red financiera; sistema bancario. 


\begin{abstract}
Resumo
Operando de acordo com uma lógica coerente e instrumental, as redes formam sistemas que permitem a circulação de capital e governam a reprodução e evolução do espaço geográfico, fraturando cada país em homens rápidos e lentos e em áreas luminosas e letárgicas. Finanças não evadem essa lei geral. Neste trabalho, a reorganização da rede financeira e do sistema bancário na Argentina entre 1991 e 2008 são estudados para caracterizar a racionalização e fragmentação do país em curso. A análise dos objetos, das ações e das regras que compõem a divisão peculiar do trabalho e da interpretação de fatores externos (crises internacionais, regulamentos globais, as estratégias de acumulação de capital estrangeiro) e internos (o papel do Estado, o funcionamento político e técnico circuito, as relações com outras formas e estruturas espaciais) - por meio de indicadores como a globalização e a concentração econômica e dos negócios do setor, as densidades locais do tecido bancário, o nível de automação e o movimento de capital-dinheiro mostrará, para nível provincial e departamental, o estabelecimento de áreas luminosas totalmente integradas e áreas letárgicas e excluídas.
\end{abstract}

Palavras-chave: circulação do capital; rede financeira; sistema bancário.

\begin{abstract}
Operating through a coherent and instrumental logic, networks form systems that, allowing the circulation of capital, preside over the geographical space's reproduction and evolution, fracturing to each country in quick and slow men, in luminous and lethargic areas. Finances don't avoid this general law. In this paper, the reorganization of the financial network and bank system in Argentina during the period 1991-2008 is studied to characterize the current rationalization and fragmentation's process of national territory. The analysis of objects, actions and norms that compose that peculiar division of labor and the interpretation of external (international crisis, global regulations, foreign capital accumulation strategies) and internal factors (paper of national State, circuit's technical and political development, relationships with other spatial forms and structures) that govern it -through indicators as bank system's globalization and economic concentration, territorial densities bank tissue, their automation level and money-capital movements- will reveal, to provincial and departmental scale, the fully integrated luminous and excluded lethargic areas.
\end{abstract}

Keywords: capital circulation; financial network; bank system.

\title{
Introducción
}

Siguiendo una lógica coherente e instrumental, las redes forman sistemas que, permitiendo la circulación del capital, presiden la reproducción y evolución del espacio geográfico mediante un movimiento desigual y combinado que obedece tanto a fuerzas centrípetas como centrífugas. En este trabajo, se aborda la reorganización de la red financiera y del sistema bancario en Argentina durante el período 1991-2008 para caracterizar el actual proceso de reestructuración y segmentación del territorio nacional. Siempre en función de la comunión entre factores externos e internos, se pretende identificar, a 
partir de los objetos, las acciones y las normas que componen esa división territorial del trabajo, las áreas luminosas y letárgicas forjadas en virtud del trazado y funcionamiento de la red. En primer lugar, se realizará una breve aproximación teórica a los conceptos de espacio geográfico y redes, y una escueta caracterización del sistema financiero, definiéndolo como una forma ficticia o ilusoria del capital. Seguidamente, se realizará un sucinto relato del devenir histórico de la acumulación financiera en nuestro país, para luego desarrollar exhaustivamente el núcleo del presente artículo -la reestructuración económica y espacial del sistema bancario nacional-. A la luz del concepto de acumulación por desposesión, el estudio de la enajenación del patrimonio público, las estrategias del capital extranjero, la concentración empresarial, las crisis internacionales, las regulaciones globales y el papel del Estado, permitirá analizar el funcionamiento técnico y político del sistema a partir de variables geográficamente diferenciadas a escala provincial y departamental, como las densidades del tejido financiero, su nivel de automatización, los movimientos de capital-dinero (depósitos, créditos), y sus nexos con las funciones económicas y las jerarquías urbanas. Finalmente, se presentarán las conclusiones a las que el trabajo ha arribado.

\section{Espacio geográfico, redes y capital financiero: elementos conceptuales}

El espacio geográfico es el territorio explicado a partir de sus usos (SANTOS Y SILVEIRA, 2001), un conjunto indisoluble, solidario y contradictorio de sistemas de objetos y acciones mediados por las normas (SANTOS, 1996), síntesis de las redes y la división territorial del trabajo. Objetivada como un híbrido de materialidad y poder, cada red despunta como una entidad socio-técnica, compuesta por fijos -puntos de cálculo (autonomía) y de control (dependencia) (REMY y VOYÉ, 1981; SILVEIRA, 2003) - y flujos -tangibles e intangibles- que conectan y articulan a aquellos. Ontológicamente, las redes participan de la composición existencial del espacio, más al mismo tiempo se separan de aquél, orientándose a presidir su funcionamiento y reproducción.

Operando a partir de una racionalidad instrumental y pragmática, las redes obedecen a un comando externo y centralizado que, fundado en la discontinuidad territorial y la proximidad organizacional, genera fenómenos de dispersión y concentración, homogeneización y heterogeneización, unificación y fragmentación, estabilidad y metamorfosis, sístole y diástole. Signado tanto por la exacerbación de las brechas preexistentes cuanto por la creación de nuevas fragmentaciones, el espacio geográfico se segmenta en 'hombres rápidos' y 'hombres lentos' (SANTOS, 1993). Si bien ese proceso se verifica 
también en otros sistemas hegemónicos -transporte, energía, comunicaciones-, las finanzas constituyen una de sus más acabadas manifestaciones.

Sofisticada y compleja, esa red halla en el dinero y el crédito los fundamentos de su poderío. Ora como forma particular de circulación del capital, ora como bloque social hegemónico -una facción de la burguesía(HILFERDING, 1970), las finanzas son la columna vertebral del modo de producción y la fuente suprema del poder social. Sin materializarse jamás, el dinero fluye por la red financiera, convirtiéndose en una señal, una orden (RAFFESTIN, 1990) que no hace más que recrear la ilusión fetichista de un mundo fantástico, fabuloso, de riquezas y activos en papel (HARVEY, 1988).

Siguiendo a Marx (1968), el capital financiero es ficticio: nacido del capital a interés, carece de sustancia real; no es más que un autómata que, borrando toda conexión con el excedente en tanto producto del trabajo social, se valoriza a sí mismo y por su propia virtud. Objetivado en la acumulación de derechos respecto de una plusvalía producida o a producir (SERFATY, 2000), ese capital se nutre de títulos de deuda y, sobre todo, del crédito': pero a excepción del fondo de reserva, la inmensa mayoría del dinero concentrado en las instituciones financieras es puramente ficticia, no existiendo nunca en depósito; son meros saldos en poder de los banqueros, convertidos en capital a partir de préstamos otorgados a terceros (HARVEY, 1988). Ello ocurre por que las finanzas desarrollan una dialéctica real-imaginaria (CARCANHOLO Y SABADINI, 2008), que permite al dinero metamorfosearse en capital y circular de una esfera a otra sin necesidad alguna de producción material o intercambio concreto de mercancías (HARVEY, 1988).

No obstante, las ganancias derivadas de esa forma de valorización del capital son, en términos individuales, reales; las transferencias de valor y plusvalor que suponen influyen sobre la distribución del ingreso, incrementando la riqueza de sus poseedores -grupos sociales concretos, en absoluto ficticios- (CHESNAIS, 2008). Sin embargo, desde el punto de vista del excedente global, no se trata sino de fugaces rentas diferenciales resultantes de la especulación, que permiten hacer realidad el ideal de la burguesía -hacer dinero del dinero, evitando el doloroso proceso de la producción (MARX, 1968)-.

Omnipresente y abstracto, el sistema financiero consolidó su largamente forjada supremacía con el surgimiento, a partir de 1973, de

1 El capital ficticio reconoce tres orígenes: a) transformación en títulos negociables del capital ilusorio; b) duplicación aparente del valor del capital a interés, como ocurre en el caso de las acciones y los títulos públicos; y c) valorización especulativa de los diferentes activos (CARCANHOLO Y SABADINI, 2008). 
primigenias formas inmateriales de dinero; condensado en estado puro (SANTOS, 2000), ese dinero resultaría despojado de todo nexo formal con los metales preciosos para pasar a ser tasado en cifras nominadas en monedas con tipos de cambio sumamente volátiles (HARVEY, 1990). Surgía, pues, el capital especulativo parasitario (CARCANHOLO Y SABADINI, 2008), que convirtió a la prolongada -y actualmente en curso- fase de acumulación de valores ficticios en el hilo conductor de la historia económica reciente del mundo capitalista central (CHESNAIS, 2008). La circulación del dinero, devenida global, exacerbaría su invisibilidad y, paralelamente, ganaría fluidez gracias a la entronización de las nuevas condiciones políticas -la llamada 'desregulación' - y los notables progresos suscitados en las telecomunicaciones, la telemática, la electrónica y la informática, plasmados en operaciones más rápidas, mercados extremadamente volátiles y, también, la interconexión en tiempo real de bolsas y bancos (SANTOS Y SILVEIRA, 2001).

La denominada 'ingeniería financiera' operó desdoblando al capital ficticio en innumerables tentáculos, dando lugar al espectacular crecimiento de los flujos de títulos e inversiones -acciones, obligaciones, fondos de pensión, seguros-: si en 1988 las operaciones usurarias, rentísticas y especulativas de los países de la OCDE cuadruplicaban los guarismos del PBI y del comercio exterior (BRIONES ROUCO, 2002), el ocaso del Siglo XX sería testigo de la frenética danza de nada menos que 1 billón 300 mil millones de dólares -cifra sideral comparada con los 20 mil millones transados cinco lustros atrás en las principales plazas financieras- y, además, de un volumen de especulación que, cincuenta veces superior al comercio mundial de bienes y servicios (SOLER, 2001), fluye incansablemente durante las 24 horas del día por redes informacionales mundializadas como Reuters, Bloomberg, CNNFN y NBC.

Obediente a una inteligencia global, esa red no es anárquica; aquí, el mito de la mano anónima e invisible del mercado es aún más falaz que en el resto de la economía: el bloque de poder que controla el capital-dinero no supera el centenar de grupos. Las monstruosas dimensiones de Wall Street y el papel desempeñado por la Reserva Federal como re-aseguro para las acreencias permiten a Estados Unidos disponer a voluntad de un inmensurable caudal de capitales; así, la circulación financiera escapa a los limitados mecanismos de control de los bancos centrales (MACEDO CINTRA, 2000). El mercado de cambio de las principales divisas es manejado por sólo cincuenta bancos, apenas una decena de empresas financieras controla el $40 \%$ de las operaciones bursátiles (BRIONES ROUCO, 2002) y un puñado de firmas globales e inversores 'institucionales' regula el reparto de colosales concentraciones de capital-dinero en 'estado puro'. Constituida por la Reserva Federal estadounidense, la bolsa neoyorquina, los bancos transnacionales y las instituciones financieras supra-nacionales -FMI, Banco Mundial, Club de París, 
etc-, una geografía de los controles impone, en todos los países, una familia de acciones que, procurando extinguir las fronteras políticas nacionales (SILVEIRA, 1999), las transforma en una fuente de lucro, beneficiando a los actores globales con diversos instrumentos de la macroeconomía -conversiones entre sistemas monetarios, balances de comercio exterior, pago de royalties, deudas públicas y privadas, etc- (SANTOS Y SILVEIRA, 2001).

Así como las redes integran el espacio y se independizan de él para regularlo, las finanzas ganan una existencia y un comando relativamente autónomos en relación al resto de la economía, imponiéndose como una regla de reglas sobre la totalidad del edificio social (SANTOS, 2000). No obstante, el sistema financiero es extremadamente frágil: basta que la fría racionalidad del cálculo sucumba al caos y la imprevisibilidad propios de la ebullición de los mercados para que un juicio apresurado, una palabra desconsiderada o una reacción espontánea se conviertan en el desliz que haga tambalear todo el armazón que sustenta la formación del capital ficticio; así, el papel del dinero como medio 'seguro' de representación del valor puede hacerse añicos (HARVEY, 1990).

Obstando sus especificidades, todas las redes demarcan, a escala global y nacional, zonas o áreas de densidad y raridad, de fluidez y viscosidad, espacios del mandar y espacios del hacer, geografías luminosas y geografías letárgicas (SANTOS Y SILVEIRA, 2001). El sistema financiero no evade esa ley general. Surgen, por un lado, los espacios del mandar: ordenadores de la producción, el movimiento y el pensamiento, constituyen áreas luminosas primarias que concentran las instancias internas de control del país como un todo, pero respetan los designios del mundo, ejerciendo una regulación delegada (SILVEIRA, 1999; SANTOS Y SILVEIRA, 2001). Otros espacios emergen como islas de modernidad -lugares dependientes, alienados, teleorganizados-, donde se objetivan fragmentadamente algunas funciones modernas, desarrollando una luminosidad secundaria (SILVEIRA, 1999). Ora primaria, ora secundaria, esa luminosidad revela puntos y áreas devenidos locus de los eventos del nuevo orden global -objetos perfectos e importados, actividades hegemónicas, acciones racionales y pragmáticas, normas universales, agentes de la economía global y una circulación veloz, fluida, desarrollada en tiempo real-; aquí el territorio es más 'racional', más apto para producir lo que tiene valor en ese momento, más poblado por datos del período actual (SILVEIRA, 1999, 2008).

Surgen, por otro lado, los espacios letárgicos u opacos, repulsivos a la modernización, donde el imperio de estructuras venidas del pasado -una división territorial del trabajo pretérita, signada por formas irracionales, producciones obsoletas, acciones imprecisas, normas apegadas al pasado y 
agentes hegemonizados- (SANTOS, 1982; SILVEIRA, 1999) los integra a un 'ejército de reserva de lugares' (WALKER, 1978), donde las redes no han fijado aún sus nodos, o si éstos existen, son inadecuados para las lógicas del presente.

\section{Capital financiero y sistema bancario en Argentina: un enfoque histórico (1822-1989)}

No fue sino hasta bien entrado el Siglo XIX que los intereses estratégicos de la potencia hegemónica de turno -Inglaterra- obligaron al sistema financiero a instalarse en Argentina, confiriéndole a Buenos Aires un marcado monopolio sobre los movimientos bancarios y la emisión de moneda. Con el surgimiento del 'modelo agroexportador' (1870-1930), la eclosión del moderno Estado-Nación y la constitución de un mercado interno apto para la libre circulación del capital, esa racionalidad se afianzó; fundada en la hegemonía del patrón oro, la Caja de Conversión fue creada, en tanto el Banco de la Nación Argentina (BNA) sustituyó al Banco de la Provincia de Buenos Aires (BPBA) en la emisión de dinero, en un contexto en el cual el país se había tornado extremadamente dependiente de las crisis cíclicas de la economía británica. Los bancos porteños, financiados con empréstitos internacionales y rentas obtenidas de las exportaciones agropecuarias, contaban con garantías públicas (SILVEIRA, 1999).

No obstante, la época de bonanza fue efímera: la crisis de 1929 obligó a recurrir a las reservas monetarias para compensar la caída del poder de compra de las exportaciones, la imposibilidad de comprimir a igual ritmo las importaciones y soportar el cierre de los mercados internacionales, el abandono de la libre transferibilidad de divisas y el trastrocamiento del flujo de capitales extranjeros. Hacia la década de 1940, la 'industrialización sustitutiva de importaciones' (1930-1970) convocó al sistema bancario doméstico a colaborar con el incipiente desarrollo manufacturero de la economía argentina; esto implicó la supresión de la Caja de Conversión, el abandono del patrón oro y el surgimiento del Banco Central de la República Argentina (BCRA), que hasta la finalización de la Segunda Guerra Mundial permaneció bajo el control informal de los intereses británicos, que regulaban, a través del Instituto Movilizador de las Inversiones Bancarias, la política crediticia del país (ROFMAN Y ROMERO, 1997).

Obedeciendo a los intereses estatales, surgieron asimismo entidades como el Banco Industrial de Desarrollo (BID), el Banco Hipotecario Nacional (BHN) y el Banco de Crédito Industrial (BCI) que, otorgando préstamos promocionales de mediano y largo plazo a las empresas manufactureras domésticas, consiguieron retrasar el ingreso de Argentina a las instituciones de 
Bretton Woods -Fondo Monetario Internacional (FMI) y Banco Internacional de Reconstrucción y Fomento (BIRF, actual Banco Mundial)-. Sin embargo, el Banco Nación continuaba siendo el corazón del sistema, pues emitía moneda, concentraba la mitad de los depósitos y era el clearing-house de las demás instituciones financieras (SILVEIRA, 1999). Ostensible, el declive de las exportaciones agropecuarias resintió, no obstante, la prosperidad de esa fase de auge: el brutal retroceso de las reservas del recientemente autonomizado Banco Central -cayeron de 1.600 a apenas 150 millones de dólares- (FERRER, 1976) obligó a la tardía adhesión a las instituciones nacidas de Bretton Woods: así nuestro país consiguió acceder, durante la década de 1960, a los primeros empréstitos de la banca multilateral; paralelamente, la red bancaria doméstica se había consolidado como vector de desigualdad socio-territorial: el $74 \%$ de los préstamos industriales y el 53,3\% de los créditos hipotecarios, por ejemplo, era absorbido por el Gran Buenos Aires (ROFMAN Y ROMERO, 1997).

Solidaridades establecidas, en los albores de los años setenta, entre el estancamiento de la acumulación, la caída de la tasa de ganancia y de la productividad del trabajo, el incremento del desempleo, la inflación y el endeudamiento, las recurrentes devaluaciones del dólar norteamericano y la erosión del 'régimen fordista', propiciaron la eclosión, en los países centrales, de una crisis estructural que marcó el fin de la llamada 'era dorada o de postguerra', alentando, a su vez, una expansión económica y geográfica del capital financiero que, fundada en el perfeccionamiento de las redes bancarias y bursátiles, se desarrolló a expensas de la producción industrial y las naciones del 'Tercer Mundo'. Ante el exceso de liquidez derivado del exorbitante aumento del precio internacional del barril de crudo -el 'conflicto del petróleo' de 1973, que generó un flujo de petro-dólares hacia las potencias hegemónicas tan copioso que rebasó sus posibilidades de inversión productiva inmediata(ROFMAN Y ROMERO, 1997), la latente crisis de hiperacumulación fue conjurada gracias a la incompleta conquista de los mercados financieros de la periferia, vía la concesión, por parte de la banca internacional y los organismos multilaterales, de créditos a bajísimas o nulas tasas de interés. Los países periféricos absorbieron, pues, el dinero que sobraba del sistema, endeudándose a gran a escala para permitir un retorno a la escasez y la revalorización de las divisas (SILVEIRA, 1999). En toda América Latina se asistió a la lisa y llana 'fabricación' de deudas externas, que financiaron faraónicas obras de infraestructura, o bien no ingresaron al ciclo de rotación del capital productivo (BRIONES ROUCO, 2002).

En nuestro país, el antiguo modelo de industrialización comenzó a debilitarse frente a la consolidación de una dinámica de acumulación relativamente independiente del consumo de los asalariados (BASUALDO, 1987, 2003), basada en la liberalización comercial y financiera, y funcional a la 
agudización de los fenómenos de concentración, centralización y transnacionalización del capital (LEMOINE, 1987) y de surgimiento de un flamante bloque de poder y dominación (NEFFA, 1998). Se dan cita, en ese marco, la llegada de numerosos bancos extranjeros y el nacimiento de los modernos mercados bursátiles de acciones y valores, algunos incipientes, otros derivados de la metamorfosis de las primitivas bolsas de comercio; concomitantemente, la reforma financiera de 1977 -descentralización de los depósitos y del crédito, establecimiento del régimen de seguros de cambio, regulación del dinero mínimo en bancos, liberalización de la tasa de interés sobre la base de la llamada 'tablita cambiaria'²- desplazó el eje de la acumulación desde la industria hacia la especulación, subordinando a la economía doméstica ante los mercados internacionales de capitales vía mecanismos como la fuga de divisas y el endeudamiento externo (ROFMAN Y ROMERO, 1997; NEFFA, 1998; MORINA et al., 2004).

El Banco Central pasó a controlar indirectamente el crédito, permitiendo la centralización de capitales en grandes bancos nacionales y extranjeros, capaces de ofrecer rendimientos más altos y pérdidas más bajas: ya en 1979, el 56,6\% de los depósitos se hallaba concentrado en las veinte mayores entidades del sistema (FERNÁNDEZ Y TEALDO, 2002). Excluidas de los circuitos financieros mundializados, las pequeñas y medianas empresas fueron sofocadas por los costos bancarios. La especulación de la cúpula empresarial doméstica con los bancos comerciales extranjeros (GAMBINA et al., 2002) condujo a la acelerada expansión de la deuda privada, la cual fue posteriormente asumida por el Estado nacional, lo cual derivó en la quintuplicación de los guarismos correspondientes a los compromisos externos soberanos.

No obstante, todavía persistía, en el aparato estatal, un conjunto de acciones burocráticas destinadas a permitir la supervivencia de actores menos poderosos; nótese, por ejemplo, el financiamiento interno con el que, entre 1960 y 1990, se solventaron los habituales déficits de las finanzas provinciales, generalmente concretado a partir de la licuación inflacionaria de la deuda flotante y los préstamos otorgados por los bancos del interior, a su vez socorridos por los redescuentos del Banco Central (PON, 2006). Sin embargo, hacia la segunda mitad de la década de 1980, el Banco Interamericano de Desarrollo (BID) y el Banco Mundial financiaron la presurosa implementación, en nuestro país, de programas de ajuste estructural que, procurando renovar el imperio del mito de la 'mano invisible' y convertir en hegemónica a la mentada

\footnotetext{
${ }^{2}$ Los inversores externos podían, gracias a la 'tablita cambiaria', estimar con exactitud los beneficios de la especulación financiera; prefijar los valores de transacción de la moneda extranjera permitía calcular el costo de entrada y salida del mercado con suficiente anticipación (Rofman y Romero, 1997).
} 
fábula de la 'desregulación', instaron al Estado a enajenar el patrimonio público -esto es, la entrega de los 'recursos naturales' y, también, las privatizaciones y concesiones de las numerosas empresas estatales y provinciales surgidas durante los años cuarenta-, inaugurando así, en la red financiera, una larga fase de violentas reestructuraciones.

\section{Acumulación por desposesión y sistema financiero: la reestructuración de la red bancaria argentina (1991-2008)}

Harvey (2004) propone el concepto de acumulación por desposesión, intrínsecamente ligado al de acumulación primitiva u originaria en tanto que acto histórico que, basado en el despojo violento y repentino, instauró las relaciones sociales capitalistas y formó el stock de capital necesario para la Revolución Industrial europea (MARX, 1968; MANDEL, 1969). No obstante, la acumulación originaria no fue apenas el preludio de la reproducción ampliada del capital, sino que sustentó y perfeccionó la posterior evolución del sistema, permitiendo su expansión mundial, y afianzándose como fuerza importante y permanente en la geografía histórica del capitalismo; las crisis cíclicas de hiperacumulación obligan al capital a disponer siempre de un fondo exterior de activos (tierras 'vacías', nuevos mercados y fuentes de recursos) o, en caso de que aquél no exista, crearlo de algún modo: tan importante es esto para el equilibrio/perpetuación del sistema capitalista mundial, que se ha convertido en su forma dominante de acumulación -a expensas de la reproducción ampliada-, orientándose -vía el imperialismo- a la constante búsqueda de las soluciones/ajustes espacio-temporales que generen una demanda externa de inversión y/o bienes de consumo capaz de absorber el capital excedente (HARVEY, 2004).

Operando a través de la recolonización de territorios, el capital despoja a sectores, clases sociales y regiones de sus bienes o derechos adquiridos y/o colectivos, avanzando -vía prácticas predatorias- sobre formas previas de desarrollo regional (sean capitalistas o no) (GALAFASSI, 2012): así pues, a los mecanismos tradicionales -supresión de formas de producción y consumo alternativas, monetarización y tributación, usura y endeudamiento a través del crédito, desplazamiento de granjas familiares a manos de grandes empresas agrícolas, persistencia de ciertas formas de esclavitud-, se añaden otros nuevos que, propios de la actual ola de cercamiento de bienes públicos, hallan en la privatización de las empresas estatales (HARVEY, 2004) y, por ende, en la desestatización/desnacionalización del sistema bancario un mecanismo clave.

Sin lugar a dudas, los años noventa han sido, después de la Segunda Guerra Mundial, el período de mayor agitación de los mercados internacionales de capitales (DIETER, 2003). El Estado argentino restringió su otrora papel 
rector de la economía doméstica para comenzar a desempeñarse como un mero intermediario entre las -en absoluto anónimas- fuerzas del mercado mundial y el territorio. Solidaridades organizacionales entabladas entre el endeudamiento externo, la imposición de una estrecha dependencia entre la base monetaria y el dinero circulante -el Régimen de Convertibilidad que, basado en la paridad nominal entre el peso argentino y el dólar estadounidense, imperó durante el decenio 1991-2001-, la conversión a moneda norteamericana de los encajes bancarios y la apertura del tejido financiero doméstico al capital globalizado generaron condiciones propicias para que la banca extranjera se apropiara de los segmentos más rentables del sistema; antaño limitada al 10\%, la participación foránea sobre el sistema financiero doméstico ascendió al $61 \%$ (FREDIANI, 2002). España, Estados Unidos e Inglaterra eran responsables por el 79,3\% de la Inversión Extranjera Directa (IED) absorbida por el sector bancario durante la última década del Siglo XX, en su inmensa mayoría $(92,3 \%)$ destinada a cooptar entidades preexistentes (ARGENTINA, 2003).

Otrora controlados por capitales nacionales, el Banco Galicia, el Banco Francés y el Banco del Río de la Plata cayeron en manos de los grupos financieros ibéricos Santander Central Hispano (HSCH) y Santander-Bilbao Vizcaya (BBVA), respectivamente, en tanto el consorcio británico HSBC se adjudicó el Banco Roberts y la Banca Nazionale del Laboro (BNL). El Banco de Quilmes fue capturado por el grupo canadiense Scotia y el Banco Patricios resultó adjudicado al conglomerado Sorcimer. Los bancos estadounidenses tradicionales -Citibank, Bank Boston- se limitaron a expandir sus filiales, más otros bancos norteamericanos (Bankers Trust) y europeos (Crédit Agricole) se apropiaron de importantes entidades, como los Bancos de Liniers, Bisel, Bersel y del Suquía. La Caja Nacional de Ahorro y Seguro fue completamente enajenada y el Banco Hipotecario Nacional resultó objeto de una de 'privatización periférica' - el $40 \%$ fue absorbido por Ritelco, IRSA, LACP, Inversiones Financieras del Sur, IFIS, Dolphin Fund, el Deustche Bank y Administradoras de Fondos de Jubilaciones y Pensiones (AFJP's), y el 60\% quedó en poder del Banco Nación-.

El Estado nacional asistió a las firmas globales en su propósito de cooptar los principales eslabones del circuito. Sancionada en 1992, la Ley Nacional 24.485 completaría la reforma iniciada en 1977 al decretar la absoluta supresión de los controles estatales sobre la tasa de interés, el rápido desmantelamiento de las políticas públicas de crédito y la concomitante eliminación de las restricciones hasta entonces imperantes para el ingreso de flujos internacionales de capital, que alentó la llegada -y también la rápida huída- de fondos de corto plazo, esto es, los denominados 'capitales golondrina'. El Banco Central fue investido, gracias a la modificación de su régimen institucional, con la potestad de reestructurar el patrimonio de los 
bancos de acuerdo a normas internacionales -las llamadas 'recomendaciones' del Comité de Basilea-, obligando a aquellos a funcionar según criterios homogéneos y parámetros globales de evaluación mercantil de referencia aportes de capital, liquidez, ganancias, etc-.

Surgía, asimismo, una neoburocracia (SILVEIRA, 1999) constituida por organismos públicos -la Superintendencia de Entidades Financieras y Cambiarias (SEFyC), destinada a regular fusiones y adquisiciones- y entidades híbridas -Seguros de Depósitos SA (SEDESA), orientada a velar por el patrimonio de los bancos-. El Fondo Fiduciario de Capitalización Bancaria (FFCB) y los flujos de capital inyectados por SEDESA subsidiaron fusiones, absorciones y compras (FERNÁNDEZ y TEALDO, 2002). La política de redescuentos implementada por el Banco Central no mitigó la concentración del sistema en manos de los agentes hegemónicos externos, sino que más bien transfirió los costos de ésta al propio Estado, incrementando su déficit cuasifiscal (FREDIANI, 2002).

Otro episodio de acumulación financiera por desposesión lo constituyó la privatización de los bancos públicos provinciales, antaño responsables por el financiamiento de las economías regionales. Los crónicos déficits de esas entidades obligaban a los respectivos gobiernos provinciales a desembolsar grandes masas de recursos públicos para sostenerlos (CETRÁNGOLO et al., 2002). Leoninos, los empréstitos concertados tiempo atrás con algunas firmas extranjeras, las deudas de redescuentos pendientes con el Banco Central y la constitución del Fondo Fiduciario para el Desarrollo Provincial -creado ad hoc para tal fin- determinaron que, entre 1993 y 1999, los bancos públicos provinciales se redujeran a la mitad; todas las entidades entrerrianas, catamarqueñas, misioneras, salteñas, jujeñas, rionegrinas, tucumanas, puntanas, santacruceñas, formoseñas, sanjuaninas, santiagueñas y mendocinas cayeron junto a gran parte de la banca riojana y santafesina- en poder de capitales extranjeros y vernáculos -Macro Bansud, Patagonia-Sudameris, Comafi, Supervielle-Exprinter, Brunet, etc-. 


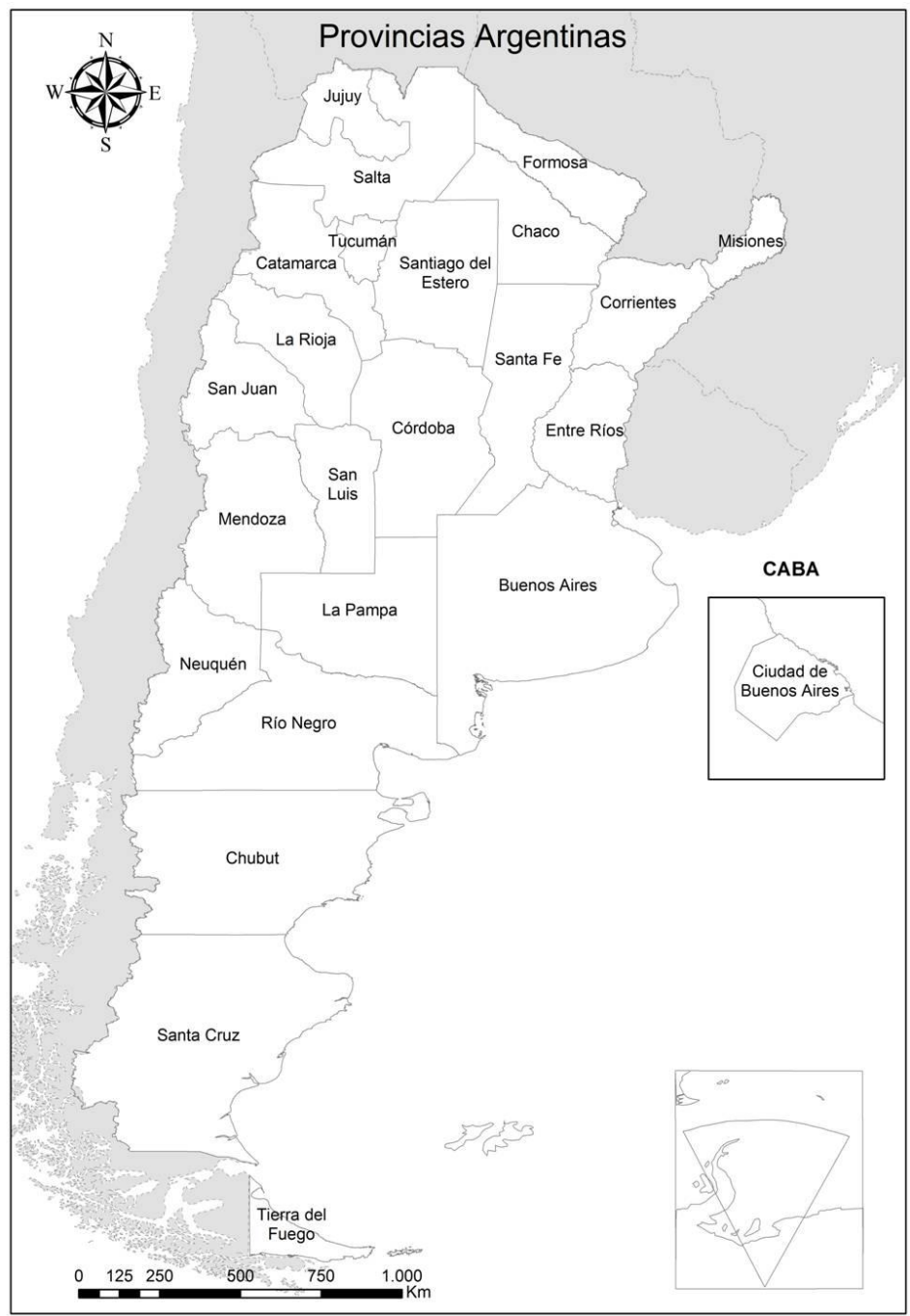

Figura 1 República Argentina, según provincias

Fuente: elaboración personal.

Obviamente, el nuevo patrón de acumulación financiera se basó en el despojo: en vez de financiar sus actividades con depósitos locales, bancos extranjeros como HSCH, BBVA, Citibank y Bank Boston lo hicieron con préstamos emitidos por sus casas matrices, diseñando así estrategias de valorización del capital ligadas al sobre-endeudamiento con el exterior; al mismo tiempo, no realizaron desembolsos genuinos, sino que colocaron gran 
parte de sus inversiones y su cartera crediticia en empresas de energía, hidrocarburos, telecomunicaciones, siderurgia y servicios y/o en consorciosconglomerados financieros diversificados partícipes de la explotación de empresas privatizadas de servicios públicos (GARCÍA, 2002, 2006a), lo cual les permitió realizar lucrativos negocios, a menudo ligados a operaciones de cartera vinculada.

No es extraño, pues, que el $65 \%$ de los préstamos otorgados por los principales bancos extranjeros se concentrara en derredor de sus 50 clientes de mayor tamaño, los cuales generalmente reconocían el mismo origen geográfico que sus acreedores: eran los casos del Scotia Bank, que financiaba a empresas mineras canadienses, o de las entidades españolas, que prestaban a firmas otrora estatales en las que poseían participación (FREDIANI, 2002). Si incluso hasta la banca pública orientaba, a finales del Siglo XX, casi el $60 \%$ de sus préstamos a las grandes empresas (BURDISSO et al., 1998). La preferencia de los bancos extranjeros por el riesgo soberano (FREDIANI, 2002) y la concentración del $50 \%$ de la cartera crediticia del Banco Nación y el Banco de la Provincia de Buenos Aires en el Estado permitían, asimismo, la reproducción del ciclo de endeudamiento externo a mediano y largo plazo (FERNÁNDEZ y TEALDO, 2002).

Sistemático e implacable, el proceso de reestructuración del sistema bancario nacional se desarrolló al compás de violentas crisis financieras internacionales -mexicana (1994), asiática (1997), rusa (1998), brasileña (1999), turca (2000), argentina (2001) y, recientemente (2008-2009), global, con epicentro en Estados Unidos- que en rápida sucesión se abatieron sobre nuestro país precipitando un caudaloso drenaje de recursos hacia el exterior, reforzando la concentración del capital e implicando una disminución del número de entidades; de hecho, entre 1991 y 1999 el número de bancos privados disminuyó un $42,2 \%$, y el de entidades cooperativas, un $95,9 \%$. La caudalosa fuga de divisas hacia el exterior precipitó el agónico final del Régimen de Convertibilidad, implicando una brutal retracción de las reservas del Banco Central, la confiscación de los depósitos de los ahorristas, la cesación de pagos de los intereses de la deuda externa y la estrepitosa caída del PBI (15\%) -la más grande de la historia argentina-.

Ostensible, la disminución -en rigor de verdad, licuación- de las deudas de buena parte de la cúpula empresarial doméstica fue inadvertidamente subsidiada por la población a partir de la llamada 'pesificación' de sus ahorros, la cual determinó que, durante el bienio 2001-2002, se produjera la transferencia de una ingente masa de recursos -alrededor de 13.132 millones de dólares- hacia el capital oligopólico (BASUALDO et al., 2003). Explícitamente asistida por el Estado nacional, la acelerada recuperación del sistema bancario 
fue el resultado de una copiosa 'indemnización' -24.300 millones de dólarescon la que el sector público 'compensó' al capital financiero por la 'desdolarización' de los depósitos que éste había impunemente drenado hacia el exterior.

Se agudizaron los ya típicos fenómenos de concentración y centralización del capital: en los albores del Siglo XXI, más de las tres cuartas partes del sistema financiero argentino habían desaparecido (FERNÁNDEZ y TEALDO, 2002), en virtud tanto de las llamadas 'regulaciones prudenciales' impuestas por el BCRA -destinadas a garantizar una mayor solvencia patrimonial en los distintos nodos de la red- (SILVEIRA, 1999) cuanto de la hecatombe de la economía nacional; así pues, de los 39 bancos extranjeros existentes en 2001, sólo quedaban 26 en 2004. La crisis alentó la retirada de numerosas entidades -Deutsche Bank, ABN-AMRO Bank, Crédit Agricole, Scotiabank, Banco Europeo para América Latina, Sudameris, Lloyds-, las cuales vendieron sus carteras minoristas o abandonaron sus filiales, algunas de las cuales consiguieron sobrevivir gracias a recursos públicos inyectados por el BCRA (GARCÍA, 2006a, 2006b).

Las operaciones del Kookmin Bank y del Banco do Estado de São Paulo caducaron, en tanto el Nuevo Banco Bisel, el Nuevo Banco del Suquía y el Nuevo Banco de Entre Ríos fueron absorbidos por el Banco Nación. El Heller Financial Bank y el Providian Bank fueron nacionalizados -hoy día Banco de Servicios y Transacciones y Meridian Bank-, mientras que las casas matrices nacionales del Chase Manhattan Bank y del Banco Exterior of New York fueron cooptadas por BBVA y J.P. Morgan; concomitantemente, el Scotiabank Quilmes, el Bansud, el Sudameris y el Lloyds TSB Bank PLC cayeron en manos de grupos financieros domésticos -Macro Bansud, Patagonia-, favorecidos por los redescuentos otorgados por el Banco Central.

La retirada de parte de la banca extranjera implicó un renovado acicate a la concentración empresarial y a la marcada disminución del número de filiales. Los veinte mayores bancos del sistema, que en 1993 explicaban el $68,0 \%$ de los depósitos, se apoderaban en 2005 del 89,2\%, en tanto la participación de la banca estatal, que antaño superaba las dos terceras partes del total, se desplomó hasta el 35,0\%. Sólo dos bancos públicos -BNA y BPBA-, los grupos financieros ibéricos - $\mathrm{HSCH}$ y BBVA-, las entidades norteamericanas -Citibank y Bank Boston- y la principal institución británica HSBC- acaparaban el 67,9\% de los volúmenes de dinero inyectados a la red. El sistema de crédito continuaba siendo dinamizado por agentes estatales $(30,5 \%)$ secundados por el capital hispánico $(30,0 \%)$. Si veinte empresas reunían el $87,0 \%$ de los préstamos, apenas seis bancos daban cuenta de más de la mitad $(55,8 \%)$. La composición de la cúpula bancaria descendió, entre 2002 y 2005 , 
de 62 a 43 entidades, de ahí que el índice de concentración Henfindahl-Hirsch aumentara de 674 a 848 puntos (GARCÍA, 2006a) ${ }^{3}$.

Otrora más poblado que el brasileño y el chileno ${ }^{4}$, el tejido financiero argentino se tornó menos denso: la desaparición de 638 filiales determinó que, si en 1994 existía una agencia bancaria cada 7.864,3 habitantes (SILVEIRA, 1999), esa relación cayera, en 2005, a una filial cada 9.198,5 personas; la merma se concentró fundamentalmente en la Capital Federal y en algunas localidades bonaerenses, cordobesas y santafesinas, donde luego las filiales de la banca pública se multiplicarían, gracias a la estatización del Nuevo Banco Bisel (GARCÍA, 2006a). Secundadas por Córdoba, Santa Fe, Mendoza, Entre Ríos y La Pampa, sólo Buenos Aires y la Capital Federal concentraban más de la mitad (51,3\%) de las agencias: así pues, siete distritos explicaban el 81,6\% de las filiales del sistema bancario. Las desigualdades regionales se volvieron aún más significativas: la espesura del tejido financiero en la Capital Federal, la pampa húmeda -La Pampa, Santa Fe, Córdoba- y la Patagonia -Santa Cruz, Chubut, Tierra del Fuego- contrastaba con rincones casi vírgenes del territorio nacional -Formosa, Salta, Jujuy, Tucumán y Santiago del Estero-, donde el sistema bancario se hallaba apenas presente en las respectivas cabeceras provinciales; la cobertura bancaria de la Capital Federal era 2,2 veces superior a la de Santa Fe y 8,1 veces más densa que la de Formosa.

Sin embargo, la pérdida de espesura del tejido financiero argentino fue paralela a la evolución de su nivel de automatización. Solidaridades técnicas entabladas entre los satélites y los sistemas informáticos permitieron que un sistema técnico miniaturizado -la red de cajeros automáticos- suplantara al trabajo humano por la racionalidad de las máquinas. Obstando la reducción del número de filiales bancarias (6\%) registrada entre 2001 y 2005, la dotación de cajeros automáticos aumentó un $8 \%$, lo cual acentuó el ya predominante fenómeno de reducción de la plantilla laboral de los bancos, que disminuyó un $68,8 \%$ en apenas una década $(1993-2003)^{5}$. Hacia comienzos del Siglo XXI,

\footnotetext{
${ }^{3}$ En Europa y Estados Unidos -donde impera la 'libertad de mercado' y, asimismo, la economía se encuentra más que concentrada en manos de las grandes corporaciones-, los gobiernos suelen intervenir para evitar la oligopolización del mercado cuando ese índice supera los 200 puntos (GARCÍA, 2006a).

${ }^{4}$ En 1994, la densidad del tejido financiero argentino era inferior a la de España -una agencia bancaria cada 2.206 habitantes- y Estados Unidos -una filial cada 3.707 habitantes-, más superior a la de Brasil y Chile -una relación de una agencia cada 8.585 y 10.691 habitantes, respectivamente- (SILVEIRA, 1999).

5 Si en 1993 había 167 bancos con 117.742 empleados, en diciembre de 2003 sólo quedaban 75 entidades con 83.833 trabajadores. Sólo entre 1990 y 1999, la banca pública se desprendió del $20 \%$ de sus empleados. Los bancos privados expulsaron el $25,1 \%$ de su plantilla laboral en ese lapso, con un pico situado en el orden del 32,8\% entre 1993 y 2003 (para más detalles, consultar García, 2006a).
} 
existía un cajero automático cada 7.000 habitantes -esto es, la sexta parte del ratio predominante en los países centrales (FREDIANI, 2002) -, pero un lustro después se verificaría la proporción de una máquina cada 5.130,9 personas (GARCÍA, 2006a).

Sin embargo, esa modernización era territorialmente selectiva: exceptuando a Tierra del Fuego, Buenos Aires y Capital Federal, más del 40\% de las sucursales bancarias del resto del país carecía de cajeros automáticos; sólo cinco jurisdicciones -Capital Federal, Tierra del Fuego, Santa Cruz, Neuquén y Chubut- rebasaban la media general; Buenos Aires y la Capital Federal, que concentraban el 60,7\% de los cajeros, acaparaban -junto a Santa Fe, Córdoba, Mendoza y Entre Ríos- el 80,7\%. Los contrastes regionales son, ciertamente, agudos: la cobertura metropolitana era 8,5 superior a la santiagueña, 4,9 veces mayor que la sanjuanina y 3,3 veces más elevada que la bonaerense. En las áreas poco pobladas o casi excluidas por las redes financieras -el norte argentino, San Juan, Córdoba, Tierra del Fuego, Neuquén-, las capitales provinciales concentran entre la mitad y las tres cuartas partes de las filiales automatizadas (ARGENTINA, 2006).

Opacas, las áreas letárgicas se revelan ajenas al frenesí propio de la circulación financiera automatizada, intersticios y vacíos donde algunas solidaridades orgánicas permiten la reproducción, en medio de la quietud y el letargo, del cotidiano: en remotos parajes del interior del país y, sobre todo, en recónditos rincones de la Patagonia, la ausencia de cajeros automáticos pretende ser suplida o, al menos, compensada por empresas que prestan servicios especiales de transporte de caudales y correo de dinero, transitando caminos provinciales y vecinales con una frecuencia quincenal o mensual para pagar los sueldos del sector público y de algunas firmas privadas. Se trata, pues, de lugares habitados por los 'hombres lentos' sobre los cuales escribe Santos (1993), ajenos a la aceleración y la fluidez de las metrópolis y las ciudades grandes y medias.

Harvey (2004) explica que, a partir de la espectacular oleada de financiarización iniciada en 1973, el sistema mundial de crédito ha adquirido un sesgo marcadamente especulativo y depredador. Argentina no ha sido una excepción a la regla: en efecto, la oferta estatal de crédito disminuyó frente a la desaparición del Banco Industrial de Desarrollo y la reestructuración del Banco Nación; entre 1990 y 2001, el número de receptores de préstamos creció un $427,8 \%$, pero la masa de depósitos, un $800 \%{ }^{6}$ (FREDIANI, 2002); luego de la crisis, la relación crédito/ahorro se desplomó del 80\% (2002) al 58\% (2005)

6 Eran menos de 10.000 millones de dólares en 1990, 47.000 millones de dólares en 1994, 78.000 millones de dólares en 1998 y 80.000 millones de dólares en 2001 (FERNÁNDEZ y TEALDO, 2002; FREDIANI, 2002). 
(GARCÍA, 2006a). Extractiva y especulativa, la lógica de funcionamiento del sistema bancario argentino acentuó la acumulación por desposesión.

El sistema de créditos y depósitos bancarios posee una doble propiedad: desde una perspectiva espacial, se trata de un poderoso mecanismo de segregación social y fragmentación territorial, obediente tanto a ritmos externos como a esquemas internos de materialidad y poder que han sido legados por el pasado y cristalizados en el presente; y desde una perspectiva económica y social -señalan Santos y Silveira (2001)-, es un acto de imperio del sistema financiero, que permite a éste ganar dos veces, primero aglutinando el dinero otrora disperso y luego lucrando con la anticipación de aquél para el consumo. Se impone, pues, analizar los cambios suscitados en la configuración espacial de los flujos de capital-dinero, a la luz de la reorganización de las finanzas argentinas, la debacle doméstica de 2001 y la crisis mundial de 2008.

Obediente a fuerzas no sólo centrípetas, sino también centrífugas, la acumulación financiera dibuja un mapa selectivo y excluyente, constituido por menos de 300 departamentos ${ }^{7}$, frente a un universo de análisis integrado por más de medio millar de jurisdicciones. A nivel general, el norte del país y gran parte de la Patagonia y Cuyo despuntaban como áreas letárgicas ajenas al frenesí de la circulación del capital-dinero, en tanto los bancos afianzaban su imperio en la pampa húmeda, el Gran Buenos Aires, la Capital Federal, las cabeceras provinciales y sus nodos secundarios; algunas localidades serían despojadas de toda participación en el sistema, en virtud de la obsolescencia de funciones de la división territorial del trabajo ligadas a la producción pecuaria y los cultivos industriales -vid, algodón, caña de azúcar, yerba mate-, lo cual implicó que ciertos departamentos tucumanos -Famaillá, Alberdi, Tafí Viejo-, santiagueños -Belgrano, Choya, Río Hondo, Robles-, misioneros -Montecarlo-, mendocinos -San Carlos, Santa Rosa-, pampeanos -Chapaleufú, Utracán-, entrerrianos -Victoria-, jujeños -Ledesma, San Pedro-, chaqueños -25 de Mayo -, correntinos -Esquina, Curuzú Cuatiá-, -cordobeses Ischilín, Totoral- y bonaerenses -Ayacucho, Madariaga, General Viamonte, General Pinto, Lobería, etc- fueran expulsados de la red.

Sin embargo, otros lugares serían incorporados al circuito bancario: comandada por la soja y otras vocaciones exportadoras -forestación, cítricos, ganadería vacuna-, la expansión de la frontera agropecuaria y sus necesidades de liquidez requirieron la presencia del sistema en rincones puntuales de Buenos Aires -Cañuelas, Carlos Tejedor, General Villegas-, Chaco -San Martín-, Córdoba -Río Primero-, Formosa -Patiño, Pirané, Pilcomayo-, Corrientes -Ituzaingó, Santo Tomé-, La Pampa -Quemú Quemú, Realicó-, San

7 En 1991, el sistema bancario incluía a 240 departamentos, en 2001 contemplaba a 247 distritos, y en 2008 había retornado a la situación anterior -240 jurisdicciones-. 
Luis -Chacabuco, Ayacucho, Gobernador Dupuy, Junín, Rawson-, Misiones Apóstoles, Cainguás, Alem, San Ignacio-, Tucumán -Yerba Buena- y Santiago del Estero -Taboada, Moreno-; a su vez, la prosperidad del turismo -sobre todo internacional- demandaría que Lácar (Neuquén), Lago Buenos Aires (Santa Cruz), Junín y Lavalle (Mendoza) se incorporaran al sistema, cuestión que, en el caso de San Antonio (Río Negro), obedecería a su inserción en la circulación portuaria globalizada.

La lógica del sistema bancario parece contradictoria porque, en principio, revela una engañosa tendencia a la dispersión: la participación relativa de los seis principales distritos -Capital Federal, Buenos Aires, Córdoba, Santa Fe, Mendoza y Entre Ríos- sobre los recursos totales de las entidades retrocedió desde el $92,0 \%$ hasta el 75,5\%. Sin embargo, esa descentralización no impidió que la Capital Federal y el Gran Buenos Aires elevaran su ya abrumadora incidencia sobre el caudal de préstamos del 56\% al 68\% (ARGENTINA, 2009); paralelamente, la participación del resto del territorio mermaría, se estancaría o, en el mejor de los casos, se expandiría débilmente.

Los grandes actores de los servicios, la industria y las finanzas enclavados en las áreas metropolitanas consolidaron un triple proceso económico, sectorial y geográfico- de concentración de la acumulación en detrimento del interior del país: en el Noroeste, los préstamos crecieron apenas un 4,4\%, pero los depósitos hicieron lo propio en un 46,5\%; en el Nordeste, el crédito se expandió un $13,2 \%$, pero la masa de capitales capturada por los bancos se incrementó un 68,7\%; en la Patagonia, la variación relativa de los préstamos fue del $-1,8 \%$, en tanto el flujo de depósitos creció un 30,4\%; en Cuyo, los créditos mermaron un $32,8 \%$, pero los depósitos aumentaron un 68,8\%; y en la Capital Federal y su conurbación, los guarismos eran del 55,9\% y el 60,4\%, respectivamente (FERNÁNDEZ y TEALDO, 2002) ${ }^{8}$; de ahí que, a comienzos de este siglo, la capital de la república concentrara el 51,8\% de los depósitos y el $64,2 \%$ del crédito, frente al $49,9 \%$ y al $55,5 \%$ detentados en 1991 (ARGENTINA, 2009).

Obediente al ya citado proceso de racionalización económica y territorial, la incorporación, durante los últimos años del Siglo XX, de ciertos puntos de nuestro país a la división del trabajo diseñada por las necesidades de

8 La división regional adoptada por Fernández y Tealdo, 2002 es aquella que considera a las provincias de Jujuy, Salta, Catamarca, La Rioja, Tucumán y Santiago del Estero como integrantes del Noroeste; a Chaco, Formosa, Corrientes y Misiones como constitutivas del Nordeste; a Mendoza, San Juan y San Luis como componentes de Cuyo; a la Capital Federal y su conurbación como parte del Gran Buenos Aires; a Neuquén, Río Negro, Chubut, Santa Cruz y Tierra del Fuego como integrantes de la Patagonia; y al interior bonaerense, La Pampa, Entre Ríos, Santa Fe y Córdoba como Región Pampeana. 
reproducción del sistema bancario argentino contrasta, empero, con el movimiento de contracción o repliegue suscitado en el seno de éste, coherente respecto de la profundización de los fenómenos de concentración y centralización del capital-dinero en un número cada vez más reducido de lugares. Si a comienzos de la década de 1990 apenas diez departamentos daban cuenta del $69,0 \%$ de la masa de ahorros y del $75,0 \%$ del caudal de créditos, en 2001 la participación de aquellos sobre los primeros se había mantenido estable, pero su incidencia sobre los segundos ya ascendía al 76,7\%; el rango estadístico correspondiente a los nodos secundarios de la red se tornó más acotado -pasó de 1,01\%-7,18\% a 1,00\%-4,10\% en el caso de los depósitos y de $1,00 \%-7,56 \%$ a $1,11 \%-2,63 \%$ para los préstamos-, erosionando la participación antaño significativa del norte y centro de la pampa húmeda, las principales ciudades de Neuquén, Río Negro, Chubut, y de las capitales el norte argentino, para aglutinar en las grandes urbes cordobesas, santafesinas, cuyanas y bonaerenses los recursos arrebatados a aquellas (figuras 2, 3, 4 y 5).
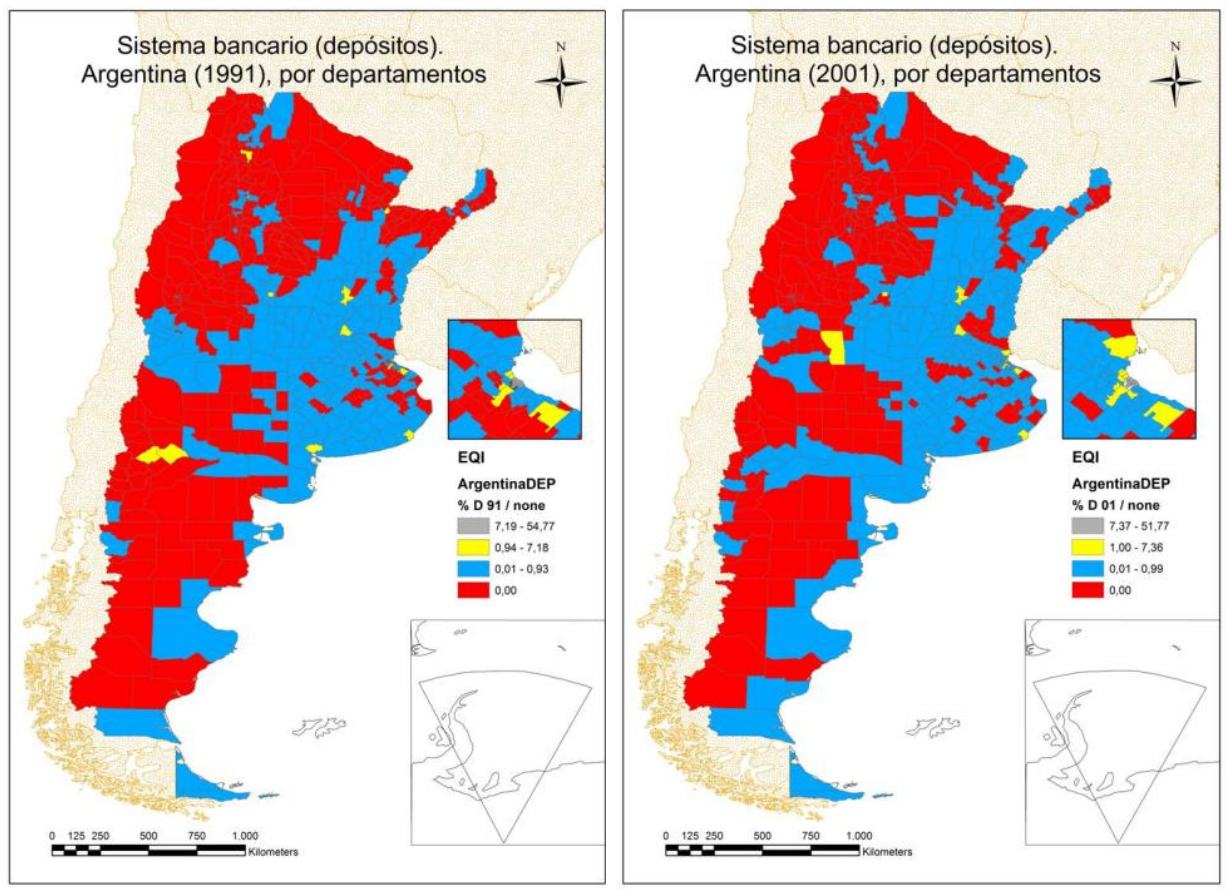

Figuras 2 y 3 Sistema bancario (depósitos). Argentina (1991 y 2001), por departamentos. Fuente: elaboración personal sobre la base de Argentina (2009). 

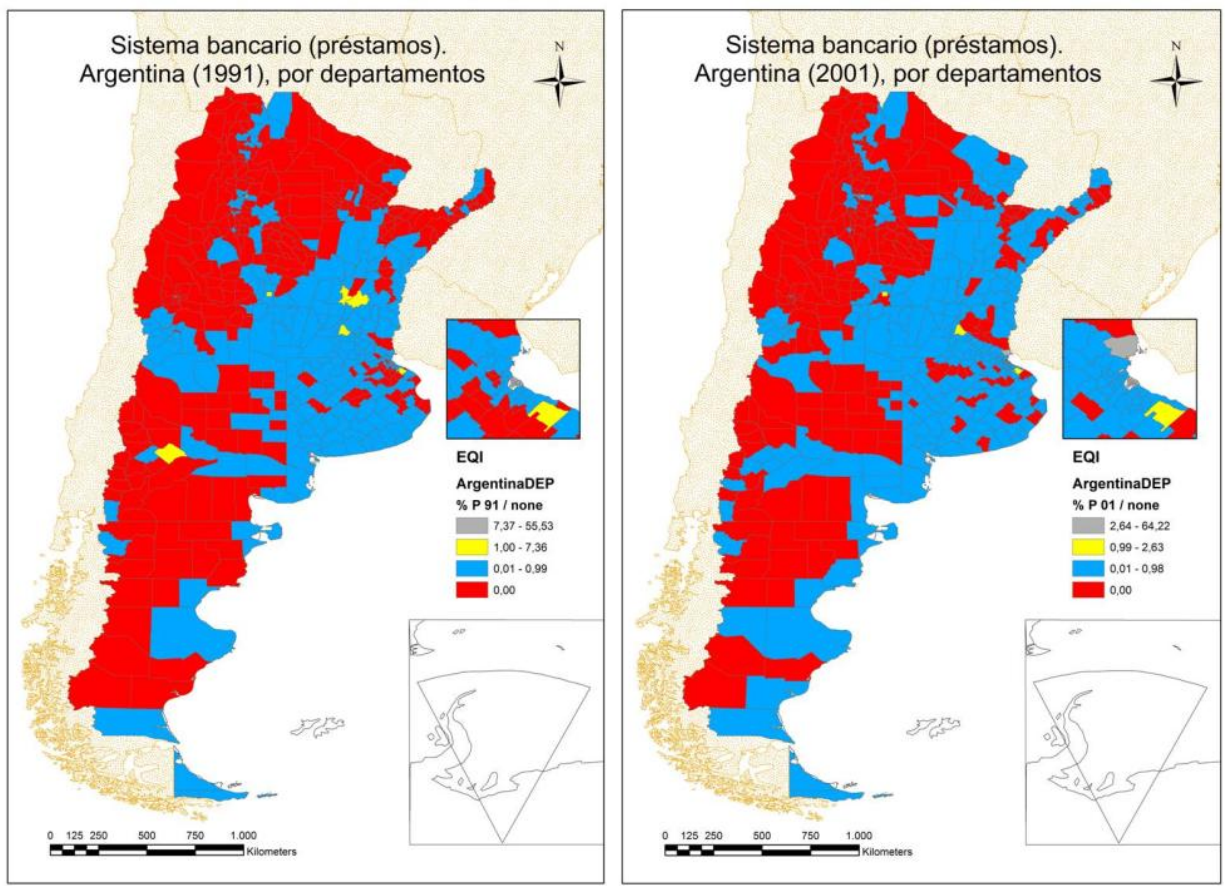

Figuras 4 y 5: Sistema bancario (préstamos). Argentina (1991 y 2001), por departamentos. Fuente: elaboración personal sobre la base de Argentina (2009).

Si a finales del Siglo XX sólo la Capital Federal, Rosario -Santa Fe- y las capitales de Buenos Aires -La Plata-, Córdoba, Santa Fe, Mendoza y Tucumán preservaban su hegemonía, el papel estratégico otrora desempeñado por San Juan, Confluencia -Neuquén- y Paraná -Entre Ríos- se había esfumado frente al incipiente protagonismo adquirido por nuevos eslabones neurálgicos del circuito, como algunos partidos del conurbano -San Isidro, Vicente Lópeze interior bonaerense -Mar del Plata-, a raíz de la prosperidad de una división del trabajo ligada a funciones agropecuarias e industriales de exportación y de la concentración geográfica de los ingresos y el poder adquisitivo.

La contribución de provincias como Tucumán, Entre Ríos, Chubut, Salta, Chaco, Corrientes y San Juan a la aglutinación de dinero en los grandes bancos se tornó más significativa, aunque al mismo tiempo su participación en la masa de préstamos se redujo rápidamente, corroborando así la interdependencia funcional entre la expoliación de capitales hacia el centro del sistema y la apropiación, por parte de los puntos neurálgicos o estratégicos, de una parcela cada vez mayor del crédito. Se afianza, pues, el tributo, forzoso y 
cada vez más pronunciado, del interior del país a la metrópoli nacional, cuya centralidad se reproduce y expande a expensas del resto del territorio.

Sometidas a una vertiginosa vorágine, la Capital Federal, algunas capitales provinciales y las principales aglomeraciones cuyanas, patagónicas y de la pampa húmeda se revelan como áreas jerarquizadas, donde la cantidad y densidad de la población, la concentración de las riquezas, las jerarquías urbanas, la fluidez de los movimientos de capital y la espesura de la división del trabajo conspiran para centralizar el reparto de los recursos financieros. Opuesto a esas áreas luminosas, surge un vasto territorio, apenas 'tocado' por los vectores financieros: allí, la ausencia de dinamismos, la persistencia de funciones obsoletas y la lenta reproducción del cotidiano impiden la constitución de un campo fértil para la implantación, germinación y crecimiento de la simiente del capital financiero.

Con epicentro en Estado Unidos, el colapso financiero internacional de 2008 generó, a nivel doméstico, un nuevo punto de inflexión. Expoliada de la periferia $\mathrm{y}$, particularmente, de los países latinoamericanos, una gigantesca masa de recursos generó una excesiva abundancia de ahorro global que, capturada por la economía norteamericana y, en menor medida, europea británica, alemana, española, etc-, fue utilizada para subsidiar la expansión del crédito -a empresas y, sobre todo, al consumo y la vivienda- en los respectivos mercados internos de los países centrales, originando formas aún más agudas de vulnerabilidad y fragilidad, derivadas del financiamiento de una gigantesca burbuja financiera e inmobiliaria cuyo estallido desembocó en una hecatombe global sin precedentes ${ }^{9}$. En Argentina, el sistema bancario se replegó frente a la llegada de dicha crisis, aunque revirtiendo -en forma parcial- el sesgo concentrador que había desarrollado durante el período 1991-2001. Si bien la racionalidad del sistema incorporó, entre 2001 y 2008, a más ciudades del interior, ligadas al turismo internacional -Los Lagos (Neuquén), Cushamen

9 La crisis financiera estadounidense obedeció, sobre todo, a las estrategias de acumulación de las dos principales compañías inmobiliarias de ese país: Fannie Mae y Freddie Mac, las cuales se involucraron en el nicho dominado por las hipotecas subprime y sus derivados financieros, otorgando préstamos para viviendas a familias de bajos y medianos ingresos, dotadas de escasas o nulas capacidad para cancelarlos. El boom inmobiliario resultante determinó la multiplicación de títulos asociados a esos créditos que, instaurando una espiral aparentemente interminable de valorización e intercambio, fueron adquiridos por grandes bancos privados, compañías financieras y, también, por los Bancos Centrales de numerosos países, sobre todo asiáticos y, particularmente, de China. El estallido de la burbuja determinó que Fannie Mae y Freddie Mac colapsaran: sus pasivos sumaban la fabulosa cifra de 5,3 billones de dólares, esto es, casi la mitad del mercado hipotecario norteamericano y aproximadamente la tercera parte del PBI estadounidense, superando asimismo los guarismos de toda la deuda externa de ese país. Esas empresas no sucumbieron gracias al gobierno norteamericano, que las socorrió para salvaguardar sus intereses en Asia (CHESNAIS, 2008). 
(Chubut), Lago Argentino (Santa Cruz)- y a vocaciones agrícolas de exportación -Victoria (Entre Ríos), Guaraní (Misiones), Anta (Salta)-, la red se replegó, desplazando sus ejes marginales de acumulación hacia las localidades citadas, luego de abandonar algunos distritos bonaerenses -Coronel Brandsen, Dolores, General Guido, Yrigoyen, Tres Lomas-, chaqueños -Fontana-, cordobeses -Río Primero-, puntanos -Rawson- y tucumanos -Cruz Alta, Lules, Monteros, Yerba Buena-: gran parte de los departamentos incorporados algunos años atrás al sistema fue expulsada, retornando a su anterior estado de letargo.

La aparente dispersión del capital financiero enmascararía, asimismo, una centralización aún mayor que en el pasado: si bien la primacía de la Capital Federal sobre la masa de depósitos y créditos retrocedió hasta el 54,6\% y el $55,2 \%$, respectivamente, para acaparar -junto a las nueve jurisdicciones que la secundaban- poco más del $70 \%$ del reparto geográfico de ambos segmentos (ARGENTINA, 2009) ${ }^{10}$, no existirían cambios sustanciales en la composición de los nodos secundarios de la red, exceptuando el declive de Vicente López y la paralela recuperación, por parte de la capital de Neuquén, de su posición hegemónica de antaño. Obstando la disminución del peso de la Capital Federal y su conurbación, los lugares devenidos estratégicos para la reproducción de la red se tornarían más jerarquizados y menos numerosos, consolidando así una tendencia ya esbozada durante la década anterior. El comportamiento del intervalo estadístico pertinente -pasó de 1,0\%-4,1\% a 1,05\%-3,51\% para los depósitos, y de $1,11 \%-2,63 \%$ a $3,40 \%$ en el caso de los préstamos- se tradujo en la erosión del dominio de ciertos departamentos de San Luis y la capital de Mendoza, la pérdida de peso relativo de algunos partidos del Gran Buenos Aires, la recuperación de la participación de Jujuy, Salta y Confluencia, y el ascenso de la capital de La Pampa (figuras 6 y 7), siempre al compás de la pujanza de la economía petrolera y/o la agricultura de exportación.

Se asiste, paralelamente, a un movimiento concomitante de sístole y diástole, merced al cual los vectores del sistema se repliegan en algunas provincias para incrementar su número en otras. Alentada por el surgimiento de nuevos frentes de cultivo constituidos por la soja y/o el girasol -Formosa (Pirané, Pilcomayo, Patiño), San Luis (Ayacucho, Chacabuco, Dupuy, Junín)-, el algodón y la vid -La Rioja (Chilecito)-, la fruticultura -Río Negro (Avellaneda, General Roca)-, el crecimiento del turismo de sectores sociales de alto poder adquisitivo -Neuquén (Lácar), Río Negro (Bariloche), Santa Cruz (Lago Argentino, Lago Buenos Aires)-, la fluidez del comercio marítimo -Río

10 En 2008, diez departamentos -Capital Federal, La Plata, Córdoba, Santa Fe, Rosario, Mendoza, San Isidro, Confluencia, Mar del Plata y Tucumán- concentraban el 70,9\% de los préstamos y el 70,6\% de los depósitos. 
Negro (San Antonio)-, el frenesí energético -Santa Cruz (Corpen Aike), Neuquén (Zapala)- y la pesca -Santa Cruz (Deseado)-, la red bancaria doméstica se expandió en las provincias citadas; paralelamente, el dinamismo de las urbanizaciones privadas obligaría al sistema a multiplicar sus nodos en los márgenes del Gran Buenos Aires -Pilar, Tigre, San Miguel-, abandonando (o perdiendo densidad en) algunos puntos de Jujuy -Ledesma, San Pedro-, Santiago del Estero -Choya, Robles, Taboada- y Tucumán -Chicligasta-. Se corrobora así la hipótesis de García (2006a), quien sostiene que, en virtud de la notoria disminución de los recursos proporcionados desde las casas matrices, los flujos expoliados del interior del país convierten a numerosos subespacios del interior del país en financiadores netos del crecimiento usufructuado por el centro del sistema bancario.
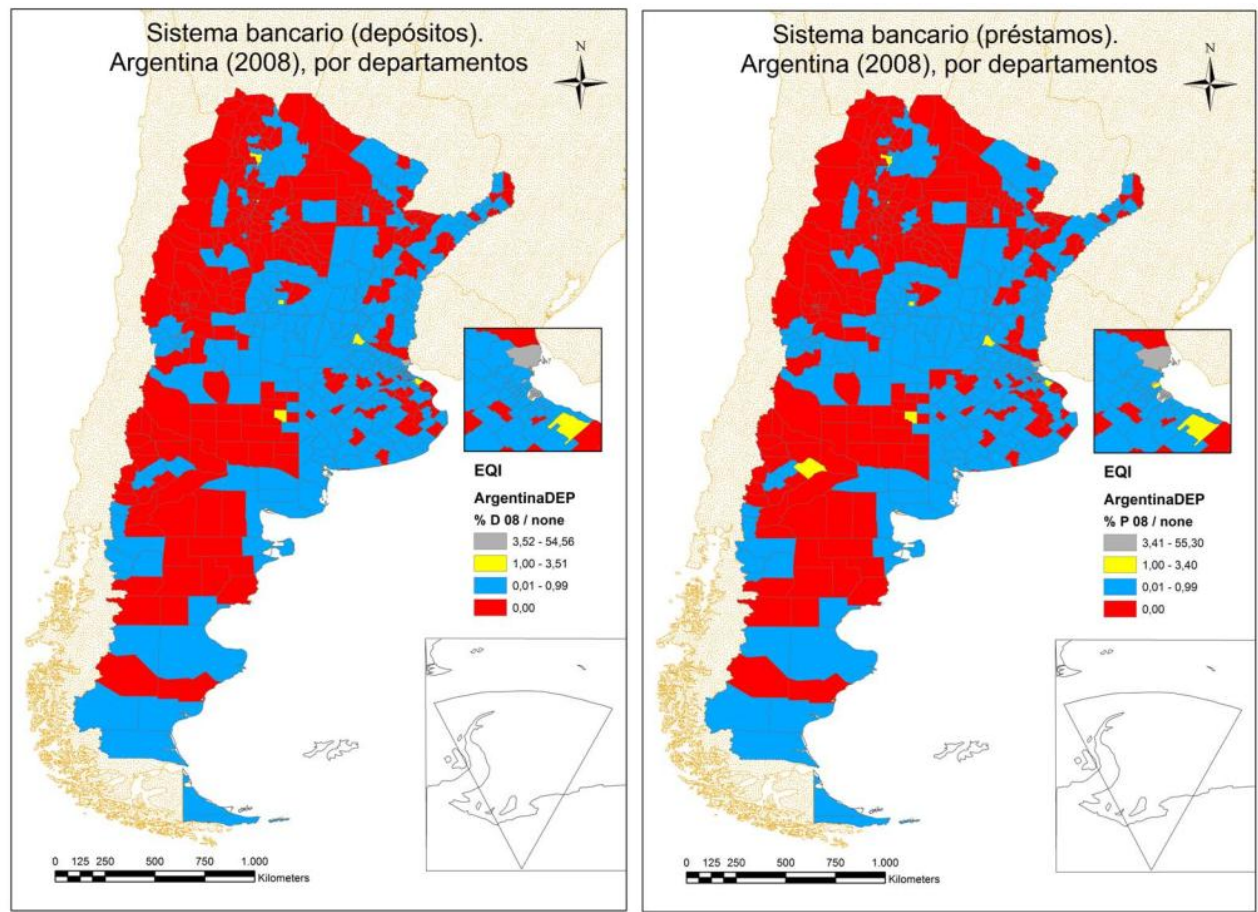

Figuras 6 y 7 Sistema bancario (depósitos y préstamos). Argentina (2008), por departamentos.

Fuente: elaboración personal sobre la base de Argentina (2009).

Siempre presente en todas las fases de modernización de la red financiera argentina, y notablemente intensificada entre 1991 y 2008, esa tendencia puede ser empíricamente estudiada a partir del análisis de la diferenciación geográfica del peso relativo o la proporción de los préstamos 
sobre la masa de depósitos; surgen, entonces, situaciones locales de déficit y superávit financiero. Hacia comienzos de la última década del Siglo XX, la inmensa mayoría del sector bancario se hallaba aún bajo el férreo control del Estado; en el funcionamiento de la red, primaba una vocación compensadora: exceptuando a algunas localidades del interior bonaerense -con énfasis en el sudeste, sudoeste y noroeste provincial- y a ciertas áreas del sur chaqueño, santafesino y chubutense, centro cordobés y norte correntino, misionero, entrerriano y santafesino, la superioridad del caudal de créditos frente al ahorro era casi absoluta (figura 8).

Sin embargo, esa situación de bonanza financiera en el interior del país sería truncada por una reestructuración del sistema bancario que colocó a sus eslabones más rentables en manos de un puñado de firmas globales, encumbrados grupos de la burguesía nacional y algunas entidades estatales refuncionalizadas por el neoliberalismo; la racionalidad expoliadora del sistema se propagó geográficamente, consumando la sangría financiera del noroeste Jujuy (capital y sudeste provincial) y Salta (capital y este provincial)-, Tierra del Fuego, gran parte de Cuyo, Misiones y Corrientes, algunos distritos chaqueños, el norte patagónico e incluso el centro y sudeste bonaerense (figura 9).
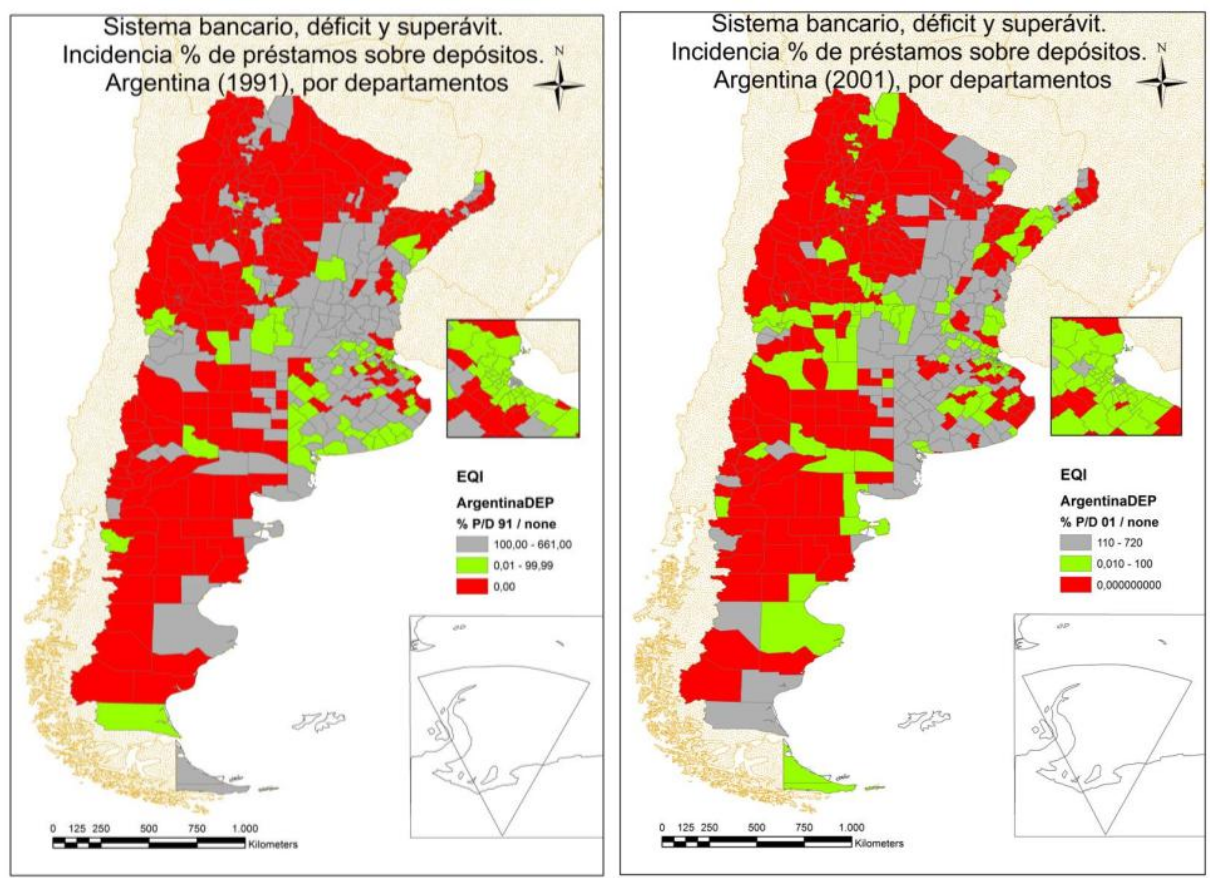

Figuras 8 y 9: Sistema bancario, déficit y superávit. Incidencia \% de préstamos sobre depósitos. Argentina (1991 y 2001), por departamentos

Fuente: elaboración personal sobre la base de Argentina. (2009) 
¿Qué decir entonces de la situación verificada en 2008, cuando ese fenómeno devino masivo -incluso extremo-, exceptuando sólo a ciertas capitales del noroeste, a fragmentos del este formoseño y del área forestal correntinomisionera, al sudeste salteño y jujeño, parte de Santa Fe, al oeste entrerriano y a minúsculas islas de Buenos Aires? (figura 10).

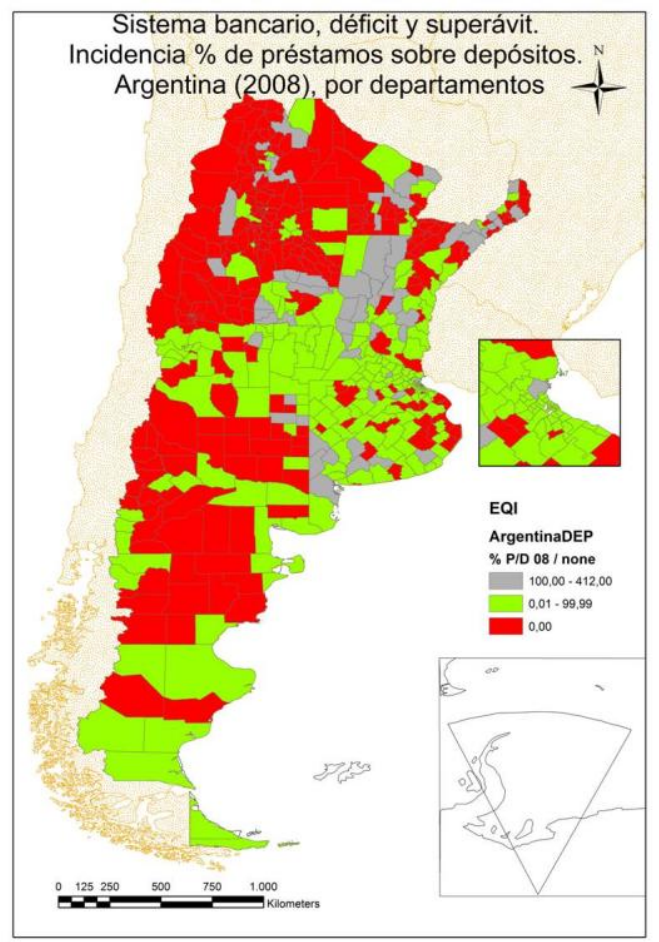

Figura 10: Sistema bancario, déficit y superávit. Incidencia \% de préstamos sobre depósitos. Argentina (2008), por departamentos.

Fuente: elaboración personal sobre la base de Argentina. (2009).

\section{Conclusiones}

Operando en un doble sentido, fundado en la creación de orden y desorden, las redes son dispersoras y, al mismo tiempo, concentradoras: desde la perspectiva de la producción del orden, se trata de la constitución de las solidaridades espaciales que interesan a los agentes hegemónicos; desde el punto de vista de la producción del desorden, de la destrucción -parcial- de los 
viejos recortes espaciales y la creación de otros nuevos (SANTOS, 1996). La circulación del capital, al presidir la producción material, cristaliza, atenúa, modifica y/o exacerba (según el caso) las jerarquías preexistentes, multiplicando las fracturas entre hombres rápidos y lentos, entre áreas luminosas y letárgicas. Segmentando el territorio, los sistemas de acciones globales forjan, junto a las normas domésticas, un orden espacial que entrelaza a los lugares vía nexos de coherencia funcional que imprimen fluidez a sus relaciones con el exterior, en un esquema ligado a la concentración empresarial y la macrocefalia geográfica.

Surge entonces un mapa -un retrato de la sociedad, la economía y el territorio argentinos- que da cuenta de la existencia de un espacio del mandar configurado por la metrópoli nacional (la Capital Federal y el Gran Buenos Aires), responsable por el comando técnico y político del sistema financiero, sede y plataforma territorial de planificación y despliegue de los movimientos de expansión y dispersión, contracción y concentración de la red bancaria. Objetos y acciones se conjugan para consolidar su posición neurálgica, reforzada por su monopolio en cuanto a la producción de las normas técnicas y jurídicas.

El interior del país participa marginalmente de la colecta y el reparto de capitales; la asimétrica redistribución del excedente permite a las capitales provinciales y los principales centros urbanos desarrollar una luminosidad secundaria, alienada, dependiente, estructurada en torno a determinadas condiciones materiales e inmateriales de existencia -funciones económicas de exportación, elevadas densidades demográficas, jerarquías urbanas, permeabilidad ideológica a los dictados de la modernidad-; dóciles ante los tiempos y regulaciones externas de la banca extranjera y la burocracia nacional, esas áreas se expresan como una atomizada constelación de enclaves, estratégicos por su papel en la automatización del trabajo y la centralización de los flujos de capital-dinero.

En el resto del país, el tejido bancario es inexistente, y su presencia de los vectores de la acumulación financiera, débil: las bajas densidades demográficas, las resistencias culturales, la primacía de una población rural dotada de bajos ingresos, la pobreza estructural, la debilidad del tejido productivo, la escasez de formas urbanas o la inexistencia de funciones modernas diseñan áreas opacas, disfuncionales para los intereses globales, verdaderos intersticios y vacíos de la red financiera. 


\section{Referéncias y fuentes cunsultadas}

ARGENTINA. Inversión Extranjera Directa, según origen y sector. Buenos Aires: Ministerio de la Producción, 2003.

ARGENTINA. Estadísticas generales del sistema bancario argentino. Filiales, cajeros automáticos. Bancos, depósitos y préstamos. Buenos Aires: Banco Central de la República Argentina, 2006a.

ARGENTINA. Estadísticas. Depósitos y préstamos por división políticoadministrativa (1991-2008). Buenos Aires: Banco Central de la República Argentina, 2009.

BASUALDO, Eduardo. Deuda externa y poder económico en la Argentina. Buenos Aires: Nueva América, 1987.

BASUALDO, Eduardo. Historia económica. Las reformas estructurales y el Plan de Convertibilidad durante la década del noventa. El auge y la crisis de la valorización financiera. Realidad Económica, Buenos Aires, n. 200, p. 42-83, 2003.

BASUALDO, Eduardo; LOZANO, Claudio; SCHORR, Martín. Las transferencias de recursos a la cúpula económica durante la presidencia Duhalde. El nuevo plan social del gobierno. Realidad Económica, Buenos Aires, n. 186, p. 54-85, 2003.

BRIONES ROUCO, Luis. Rasgos económicos del capitalismo de fin de siglo. Herramienta. Revista de debate y crítica marxista, Buenos Aires, n. 5, http://www.herramienta.com.ar/, 2002.

BURDISSO, Tamara; D'AMATO, Luis; MOLINARI, Alejandro. Privatización de bancos en Argentina: ¿El camino hacia una banca más eficiente? Buenos Aires: Banco Central de la República Argentina, 1998.

CARCANHOLO, Rodolfo; SABADINI, Mario. Capital ficticio y ganancias ficticias. Herramienta. Revista de debate y crítica marxista, Buenos Aires, n. 38, http://www.herramienta.com.ar/, 2008.

CETRÁNGOLO, Oscar; JIMÉNEZ, Juan Pablo; DEVOTO, Federico; VEGA, Daniel. Las finanzas públicas provinciales: situación actual y perspectivas. Buenos Aires: CEPAL, 2002.

CHESNAIS, Francois. Como la crisis del 29, o más. Herramienta. Revista de debate y crítica marxista, Buenos Aires, n. 38, http://www.herramienta.com.ar/, 2002. 
DIETER, Heribert. La arquitectura financiera internacional después de la crisis. Diálogo Político. Buenos Aires, n. 3, p. 31-53, 2003.

FERNÁNDEZ, Víctor Ramiro; TEALDO, Juan Carlos. Pymes: desarrollo regional y sus condicionantes macro. Dinámica de acumulación general y especificidades del sistema financiero bancario en la Argentina de los '90. Realidad Económica, Buenos Aires, n. 176, p. 114-145, 2002.

FERRER, Aldo. La economía argentina. Buenos Aires, Fondo de Cultura Económica, 1976.

FREDIANI, Ramón. El sistema bancario argentino 1990-2001. Propuestas para su reconstrucción. Actualidad Económica, Buenos Aires, n. 53, p. 11-16, 2002.

GAMBINA, Julio; GARCÍA, Alfredo; BORZEL, Mario; CASPARRINO, Carlos. Vulnerabilidad externa y dependencia de la economía argentina. In: GAMBINA, J. (Comp.). La globalización económico-financiera. Su impacto en América Latina. Buenos Aires: CLACSO, 2002, p. 259-277.

GARCÍA, Alfredo. Estructura y liquidez del sistema financiero bimonetario argentino. In: GAMBINA, J. (Comp.). La globalización económicofinanciera. Su impacto en América Latina. Buenos Aires: CLACSO, 2002, p. 247-257.

GARCÍA, Alfredo. Nuevas y viejas dinámicas en la estructura financiera.

Realidad Económica, Buenos Aires, n. 220, p. 9-22, 2006 a.

GARCÍA, Alfredo. Los nuevos bancos nacionales S.A. Realidad Económica, Buenos Aires, n. 221, p. 32-47, 2006b.

HARVEY, David. Los límites del capitalismo y la teoría marxista. Buenos Aires: Fondo de Cultura Económica, 1988.

HARVEY, David. La condición de la posmodernidad. Una investigación acerca de los orígenes del cambio cultural. Buenos Aires: Amorrortu, 1990.

HARVEY, David. El nuevo imperialismo. Madrid: Akal, 2004.

HILFERDING, Rudolph. El capital financiero. Madrid: Tecnos, 1970.

LEMOINE, Juan. Deuda externa y reconversión industrial. Realidad Económica, Buenos Aires, n. 76, p. 67-89, 1987.

MACEDO CINTRA, Marcos Antonio. 2000. La dinámica financiera internacional y la tendencia a la dolarización de las economías latinoamericanas. Realidad Económica, Buenos Aires, n. 175, p. 19-48, 2000. 
MARX, Karl. El capital. Tomo III. México, D.F: Fondo de Cultura Económica, 1968.

MANDEL, Ernest. Tratado de economía marxista. México, D.F: Fondo de Cultura Económica, 1969.

MORINA, Jorge Osvaldo; VELÁZQUEZ, Guillermo Ángel; GÓMEZ LENDE, Sebastián Discurso neoliberal, modernización hegemónica y crisis social, el caso argentino (1976-2003). Una interpretación geográfica. Anuario de la División Geografía 2004, Luján, n. 4, p. 90-111, 2004.

NEFFA, Julio César. Modos de regulación, regímenes de acumulación y sus crisis en Argentina (1880-1996). Una contribución a su estudio desde la teoría de la regulación. Buenos Aires: PIETTE-CONICET, 1998.

PON, Marcelo. El default provincial que no fue. Realidad Económica, Buenos Aires, n. 217, p. 108-126, 2006.

RAFFESTIN, Claude. Por una geografia do poder. São Paulo: Ática, 1993.

REMY, Jean; VOYÉ, Louis. Ville, ordre et violence: formes spatiales et transition sociale. París: Presses Universitaires de France, 1981.

ROFMAN, Alejandro; ROMERO, Luis. Sistema socioeconómico y estructura regional en la Argentina. Buenos Aires : Amorrortu, 1997.

SANTOS, Milton. Pensando o espaço do homem. São Paulo: Nobel, 1982.

SANTOS, Milton. Les espaces de la globalisation. Points de vue sur le Systéme Monde, París, n. 20, p. 9-22.

SANTOS, Milton. A natureza do espaço. Técnica e tempo. Razão e emoção. São Paulo: Hucitec, 1996.

SANTOS, Milton. Por uma outra globalização. Do pensamemto único à consciência universal. Rio de Janeiro-São Paulo: Record, 2000.

SANTOS, Milton; SILVEIRA, María Laura. O Brasil: sociedade e território no início do século XXI. Rio de Janeiro- São Paulo: Record, 2001.

SERFATY, Claude. Wall Street, el capital financiero y sus efectos devastadores. Herramienta. Revista de debate y crítica marxista, Buenos Aires, n. 38, http://www.herramienta.com.ar/, 2000.

SILVEIRA, María Laura. Um país, uma região. Fim de século e modernidades na Argentina. São Paulo: USP, 1999.

SILVEIRA, María Laura. Globalización y territorio usado: imperativos y solidaridades, Cuadernos del CENDES, Caracas, vol 25 (69), p. 2-19, 2008. 
SOLER, Federico. Mundialización, globalización y sistema capitalista. Globalización. Revista mensual de Economía, Sociedad y Cultura. Barcelona, n. 42, 2001.

WALKER, Richard. Two sources of uneven development under advanced capitalism: spatial differentiation and capital mobility. The Review of Radical Political Economics, New York, n. 10 (3), p. 28-37, 1978.

\footnotetext{
Sebastián Gómez Lende

Profesor de Geografía y Licenciado en Geografía por la Universidad Nacional del Centro de la Provincia de Buenos Aires (UNCPBA).

Doctor en Geografía por la Universidad Nacional del Sur (UNS), Argentina.

Investigador Asistente del Consejo Nacional de Investigaciones Científicas y Técnicas (CONICET). Investigador del Centro de Investigaciones Geográficas (CIG) y el Instituto de Geografía, Historia y Ciencias Sociales (IGEHCS).

Centro de Investigaciones Geográficas, IGECHS CONICET/UNCPBA, Tandil, CP (7000), Provincia de Buenos Aires, Argentina.

E-mail: gomezlende@yahoo.com.ar
}

Recebido para publicação em novembro de 2013 Aprovado para publicação em fevereiro de 2014 